\title{
Yağlı Boya Tuval Resimlerinin Rötuş Uygulamalarında Kullanılan Malzemeler ve Deneysel Uygulamalar: Ham ve Yanmış Sienna Pigment Örneği
}

\section{Materials Used in Oil Painted Canvas Paintings and Experimental Practices: Raw and Burnt Sienna Pigment}

\section{Berna Çağlar Eryurt}

Arş. Gör. Dr., Ankara Hacı Bayram Veli Üniversitesi, Güzel Sanatlar Fakültesi, Kültür Varlıklarını Koruma ve Onarım Bölümü email: berna.caglar@hbv.edu.tr (DORCID ID: https://orcid.org/0000-0001-6206-8818

\footnotetext{
$\underset{\text { for Aurtors \&nticearchers }}{\text { iThente }} \mathrm{Bu}$ makale bilimsel etik ve kurallara uygun hazırlanmış ve intihal incelemesinden geçirilmiştir. Etik kurul onayı gerektirmemektedir.

Atıf (APA 6)/To cite this article

Çağlar Eryurt, B. (2021). Yağlı boya tuval resimlerinin rötuş uygulamalarında kullanılan malzemeler ve deneysel uygulamalar: Ham ve yanmıș sienna pigment örneği. Atatürk Üniversitesi Güzel Sanatlar Enstitüsü Dergisi, 27(46), 44-58. https://doi.org/10.35247/ataunigsed.835656
}

Makale Gönderim Tarihi/Received: 03/12/2020

Makale Kabul Tarihi/Accepted: 10/02/2021

Makale Yayın Tarihi/Published: 29/03/202

Research Article/Araştırma Makalesi

Öz

Yağlı boya tuval resimlerinin restorasyonundaki son aşamalarından ve estetik müdahalelerinden biri olarak değerlendirilen rötuş (renksel tamamlama) geçmişten günümüze en tartışmalı onarım müdahalelerinden biri olmuştur. Malzeme, teknik, tekniğin kullanılacağı yöntem, boya, pigment, bağlayıcı çeşidi gibi birçok değişken pek çok araştırmaya konu olmuş; deneysel uygulamalar yapılarak değerlendirmelere gidilmistir. Günümüzde konuya ilişkin tartışmalar devam etmekle birlikte, her geçen gün kullanıma sürülen yeni malzemeler ile çeşitlilik daha da artmaktadır. Farklı reçinelerle hazırlanan rötus boyaları, pigment balmumu/reçineleri ve rötuş jelleri denenmekte, alternatifler aranmaktadır. Yaygın kullanılan rötuş boyaları ise hem restoratörler tarafindan hazırlanabilmekte hem de hazır olarak piyasada bulunabilmektedir.

$\mathrm{Bu}$ çalıșma, rötus uygulamalarında kullanılan yöntemlere değinerek, günümüzde tercih edilen bazı malzemeleri ve aralarındaki fiziksel farklılıkları sunmayı hedeflemektedir. $\mathrm{Bu}$ amaçtan yola çıkarak, yağlı boya tuval resimlerinin onarımında rötuşun uygulandığı iki farklı dolgu malzemesi (Bologna Alçısı ve Modostuc) ile Rönesans dönemi ve öncesinde kullanılan toprak pigmentlerden "Ham (Raw) Sienna" ile "Yanmış (Burnt) Sienna" renkleri farklı marka ve boya-bağlayıcı türleri denenerek ton, opaklık ve parlaklık gibi özellikleri değerlendirilmiștir. Rötuș için en ideal boya ve bağlayıcısının bu uygulama için üretilmiş ya da restoratörler tarafından hazırlanmış olan boyalar olduğu sonucuna varılmıştır.

Anahtar Kelimeler: Tuval Resmi, Rötuş, Boya, Ham Sienna, Yanmıș Sienna

\begin{abstract}
Retouching (color reintegration), which is considered as one of the final process and aesthetic interventions in the restoration of oil paintings, has been one of the most controversial restoration processes from the past to the present. Many variables such as material, technique, method of use, paint, pigment, binder type have been the subject of many studies. Experimental applications and evaluations were made. Today, although the discussions on the subject have been continued, the variety is increasing with the new materials that are put into everyday usage. Retouching paints, pigment wax/resins, and retouching gels prepared with different resins are tried and alternatives are sought. Commonly used retouching paints can be prepared by restorators and are available on the market as ready-made.

This study aims to present some of the materials preferred today and the physical differences between them by mentioning the methods used in retouching practices. Considering this aim, two different filling materials (Bologna Gypsum and Modostuc) to which the retouching is practiced in the restoration of oil paintings, the earth pigments "Raw Sienna" and "Burnt Sienna" which were used in the Renaissance period and before, are different brands and paint-binder types were tested and their properties such as tone, opacity, and brightness were evaluated. It was concluded that the most ideal paint and binder for retouching are paints produced for this practice or prepared by restorators.
\end{abstract}

Keywords: Canvas Painting, Retouching, Paint, Raw Sienna, Burnt Sienna

\section{Giriş}

Yağlı boya tuval resimlerindeki bozulmaların sonucu olarak boya tabakasında kanvas ve/veya astar tabakasına kadar yüzey kaybı söz konusu olabilir. Kaybın devam etmemesi ve yüzeyin devamlılığı için bu boşluk alanlar çeşitli malzemelerle dolgulanmaktadır. Beyaz ya da renkli olarak dolgulanan boşlukların estetik kaygılarla renksel olarak tamamlanması her dönemde kaçınılmaz olmuştur. Bu konudaki tartışmalar dolgunun renklendirilmesinden ziyade hangi teknikle renklendirileceği konusunda yoğunlaşmıştır. Tartışmalar farklı teknikler ve malzemeler öne çıkartılarak sürdürülmüş; bu süreç boyunca farklı okul ve atölyelerin ekolleri oluşmuştur. Günümüzde hala bu tartışmalar devam etmekte, rötuş uygulamalarında kullanılan malzemelerde çeşitliliğin artmasıyla konservatör için doğru kararı vermek güçleşmektedir.

Rötuş, bölüntüye uğramış, bütünlüğünü yitirmiş orijinal yüzeyin yeniden inşası veya görsel birlik kazandıran ilavelerin eklenmesi olarak "renklendirme" (inpainting), "kayıp entegrasyonu" (loss integration), "kayıp telafisi" (loss compensation) ve "rötuş" (retouching) (Digney Peer ve diğerleri, 2013, s. 607) gibi sözcüklerle de 
tanımlanabilmektedir. Eksik bölgenin renklendirilerek orijinal kısımlar ile görsel olarak ilişkilendirilmesi önemlidir. Yağlı boya tuval resminin bir bütün olarak genel görünümü, rötuşun ne derecede başarılı olarak yapıldığına bağlıdır.

Rötuşun tekniği, hasarın kapsamı ve türü, orijinal resmin tekniği, resmin tarihsel değeri, sanatçısı gibi unsurlar önemli olmakla birlikte, konservatörün eğitimli bir ele, resim bilgi ve becerisine sahip olması da eserin korunması için önemli bir kriterdir (Ramovs ve Hirci, 2008, s. 222). Konservatörün tekniği, malzemelerin uygun şekilde seçilmesi, kullanılması ve hangi bölgeye ne miktarda rötuş yapılacağı konusu gibi kararların doğru, hassas ve dengeli bir şekilde alınmasını gerektiren bir süreçtir. Resmin kendisi malzeme ve teknik seçimine rehberlik ederken, konservatörler çoğu zaman değişkenlik arz eden duruma uygun ideal çözümü üretebilecek rötuş bilgisine sahip olmalıdır. Rötuş, üç fazlı bir sistemin başarılı bir şekilde yapılandırılmasını içermektedir; pigment, bağlayıcı ve seyreltici. (Bailao ve Cardeira, 2017, s. 249; Nicolaus, 1999, s. 257; Digney Peer ve diğerleri, 2013, s. $607-$ $615)$.

Rötuş daima tablonun bozulmalarının belirgin olduğu, görsel olarak en dikkat dağıtıcı olan hasarlı alanlarda başlar. Rötuş işlemlerinde resim bütüncül bir yaklaşımla ele alınmalı, büyükten küçüğe hasarlı kısımlar için bir planlama yapılmalıdır. Bu şekilde resmin ne zaman tamamlanacağına karar vermek daha kolaylaşır. İşe detaydan ve ayrıntılardan başlamak büyük boyutlu resimlerde yorucu olabilir. Rötuşlar hafif bir etkiye sahip olmalı ve yakından bakıldığında belki biraz bitmemiş görünmelidir. Bazen küçük hasarlı alanlarda sadece birkaç nokta renk ile yüzey zaten düzgün görünür ve hasar artık fark edilemez görünüm kazanır (Ramovs ve Hirci, 2008, s. 226).

Bu çalışma kapsamında, rötuş uygulamalarında kullanılan yöntemlere ve günümüzde tercih edilen malzemelere değinilmiş; bunlardan birkaçı üzerinde deneysel uygulamalar yapılarak sonuçları değerlendirilmeye çalışılmıştır. Bu amaçla rötuş uygulamasının yapıldığı iki farklı dolgu malzemesi üzerine bazı farklı boya türleri uygulanmıştır. Dolgu malzemesi olarak en sık tercih edilenlerden tutkal-alçı karışımı ile hazır dolgu malzemesi kullanılmıştır.

\section{Yöntem}

Tuval resimlerinin rötuşu öncesi dolgu uygulaması için pek çok malzeme kullanılmaktadır. Bu malzemelerden en sık karşılaşılanlar, 1:17 oranında su içinde benmari yöntemiyle hazırlanan tavşan tutkalı ile Bologna alçısı karışımından elde edilen dolgu ve hazır dolgu malzemesi olarak piyasada bulunan Modostuc'tur. Modostuc, suda çözünür, geri dönüşümlü, Plasvero International tarafından ticari formüle edilmiş bir dolgu malzemesidir (Fernandez Villa, 2015, s. 203; Fuster Lopez ve diğerleri, 2008, s. 182-185). Bu iki farklı dolgu malzemesi 20x30 cm boyutlarındaki iki tuval üzerine tüm yüzeyi kaplayacak şekilde uygulanmıştır (Görsel 1).

\section{Görsel 1}

Modostuc ve Bologna Alçısı-Tavşan Tutkalı Dolgularının Tuval Üzerine Uygulanması

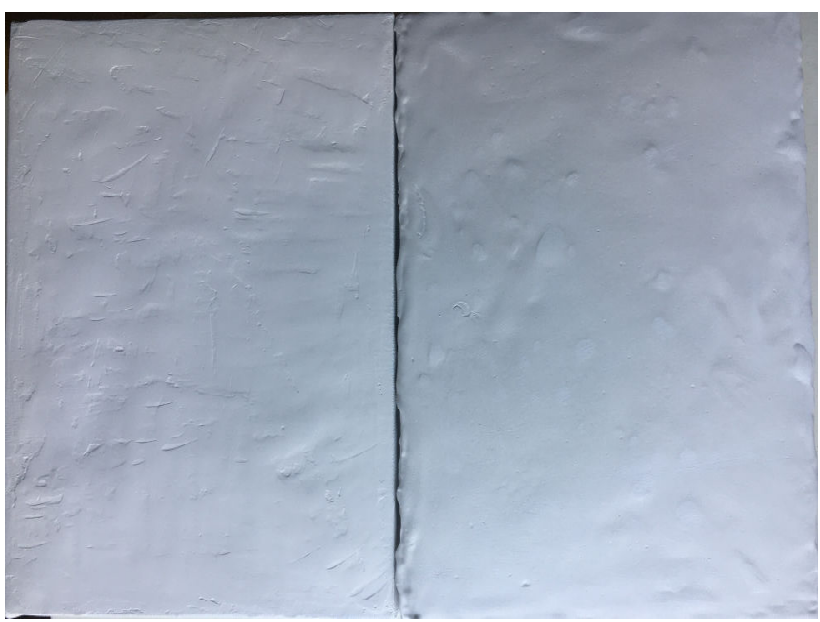

(Çağlar Eryurt, 2020).

Dolgu malzemeleri kuruduktan sonra zımpara ile düzeltilmiş ve rötuş için uygun hale getirilmiştir. Uygun yüzeyler oluşturulduktan sonra her iki dolgu malzemesi üzerine Görsel 2'deki sırayla rötuş için seçilen boyalar uygulanmıştır. Uygulama, tüm boya türlerinin renk skalalarında bulunmaları, kolay erişebilir ve kullanılabilir olmaları sebebiyle aynı kaynaktan gelen iki farklı pigment türü Ham ve Yanmış Sienna ile sınırlandırılmıştır. Bu pigmentler resim tarihi boyunca sanatçılar tarafindan kullanılmış, dirençli ve stabil bir yapıya sahip doğal toprak pigmentlerindendir. Günümüzde benzer renklerin içeriğinde de bu pigmentler kullanılmaktadır. 


\section{Görsel 2}

Rötuş Boyalarının Uygulama Şeması
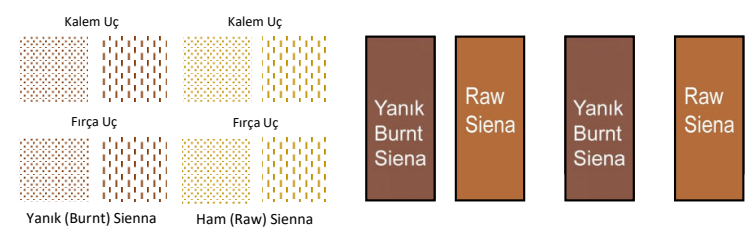

Winsor\&Newton Suluboya Markörü

\section{Winsor\&Newton}

Winsor\&Newton
Tüp Suluboya

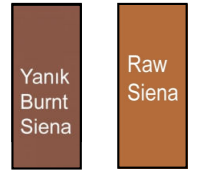

Schmincke Horadam Tüp Suluboya

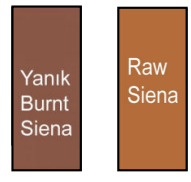

Maimeri Restauro

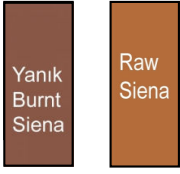

Lukas Aquarell

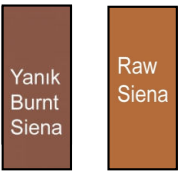

Pigment + Paraloid B72 (Aseton içinde)

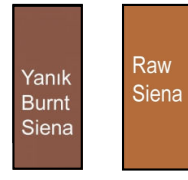

Winsor\&Newton

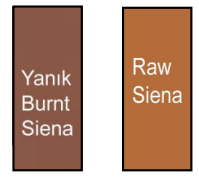

Pigment + Laropal A 8 (White spirit içinde)

(Çağlar Eryurt, 2020).

Uygulama, genellikle atölyelerde tercih edilen, piyasada kolaylıkla bulunan Winsor\&Newton, Schmincke, Lukas markaların tüp suluboyaları, Winsor\&Newton suluboya markörleri, suluboya çubukları ve guaj boyaları, Maimeri Restauro vernikli boyalar ve yazar tarafından hazırlanan pigment-bağlayıcı rötuş boyaları ile yapılmıştır (Görsel $3)$.

\section{Görsel 3}

Uygulama Sırasında Kullanılan Boya, Pigment ve Bağlayıcılar

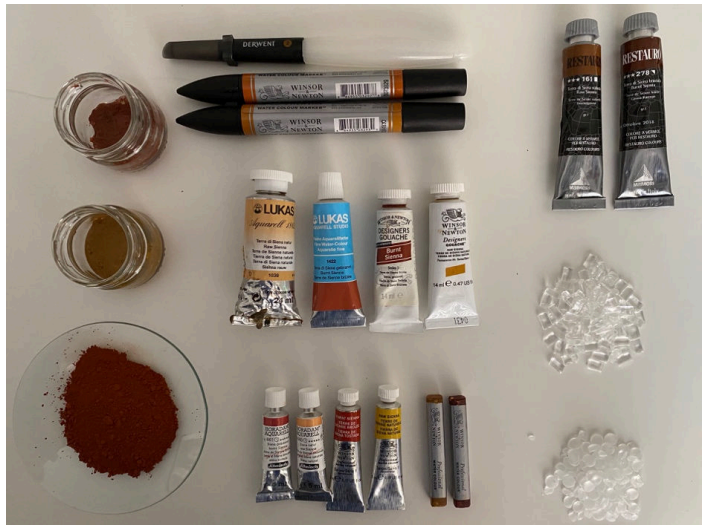

(Çağlar Eryurt, 2020)

Ham ve Yanmış Sienna pigmentleri (Sennelier Artists' Dry Pigment) bağlayıcı olarak seçilen Laropal A81 (White Spirit içinde) ve Paraloid B72 (Aseton içinde) ile rötuş boyası olarak hazırlanmışlardır (Görsel 4). Pigmentlerin bağlayıcılar ile rötuş boyası olarak hazırlanması sırasında Ramovs ve Hirci’nin (2008, s. 225-26) belirttiği noktalara dikkat edilmiştir: Pigmentler cam bir plaka ve cam havan tokmağı kullanılarak öğütülmelidir. Cam yüzeye az miktarda pigment konulmalı ve birkaç damla su ile karıştırılmalıdır. Elde edilen macun öğütülür. Bazı durumlarda başlangıçta su yerine alkol kullanılabilir. Kaba öğütülmüş pigmentler alkol ile daha hızlı çözündüğünden, bu öğütme işlemini hızlandırır. Pigmentler iyi öğütülmüşse, taneleri çıplak gözle ve firça darbelerinde görülmez, homojen kıvamdadır. İşlem tamamlandıktan sonra suyun buharlaşmasına izin verilmelidir. Temizlenmiş bir cam veya porselen yüzeye az miktarda pigment yerleştirilmelidir. 1 birim pigment, 2 birim bağlayıcı olacak şekilde homojen bir karışım elde edilene kadar spatulle karıştırılmalıdır. Bağlayıcının pigmente oranı, boyaların parlaklığını etkiler. Bazı pigmentler daha az bağlayıcı kabul eder. Hazırlanmış boyalar, temiz tutulursa iki ila üç yıl boyunca kullanılabilir. Kapaklı porselen paletler saklanmaları toz-kir yapışmaması için idealdir. 


\section{Görsel 4}

Bağlayıcılar ile Hazırlanan Rötuş Boyaları

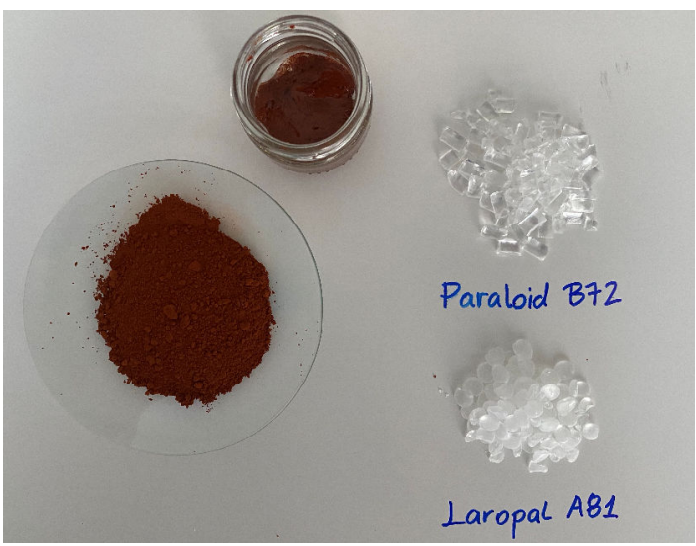

(Çağlar Eryurt, 2020).

Süreç iki farklı dolgu malzemesine aynı boya türlerinin belirlenen sırayla uygulanmasıyla gerçekleştirilmiştir (Görsel 5-6). Renklerin boya tüpünden çıktığı haliyle boyanan üst kısımlar daha sonra sulandırılarak hem renk tonunun açılması sağlanmış hem de dolgu malzemelerinin sulu bir yüzeydeki tepkisi karşılaştırılmıştır (Görsel 7). Maimeri vernikli rötuş boyası içeriği sebebiyle terebentin ile seyreltilerek kullanılmıştır. Paraloid B72 ve Laropal A81 ile hazırlanan boyalar ise bağlayıcıların hazırlandığı aseton ve White Spirit ile seyreltilerek uygulanmıştır.

\section{Görsel 5}

Modostuc Üzerine Uygulama

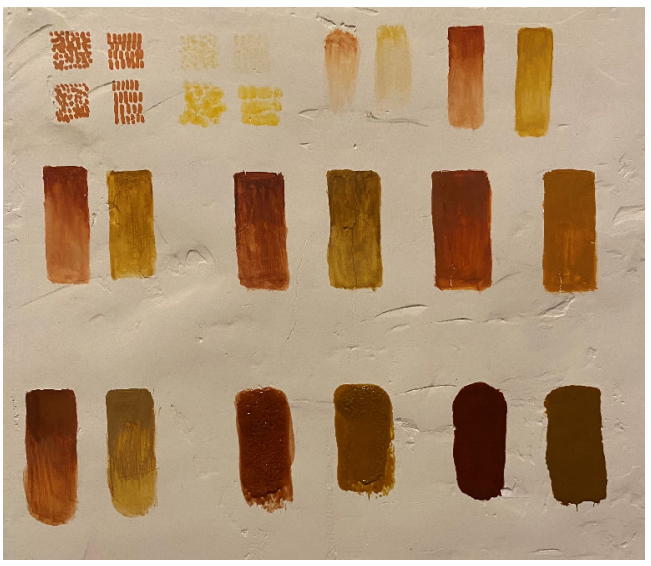

(Çağlar Eryurt, 2020).

\section{Görsel 6}

Bologna Alçısı Üzerine Uygulama

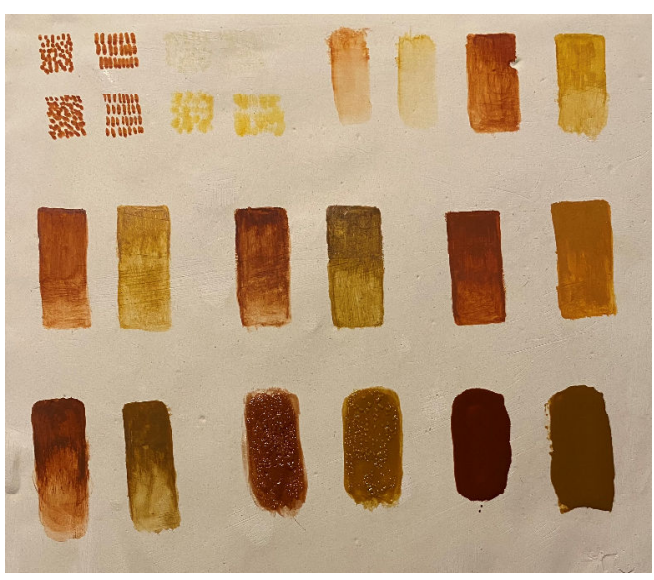

(Çağlar Eryurt, 2020). 


\section{Görsel 7}

Modostuc Üzerine Uygulanan Suluboyaların Detay Görünümü

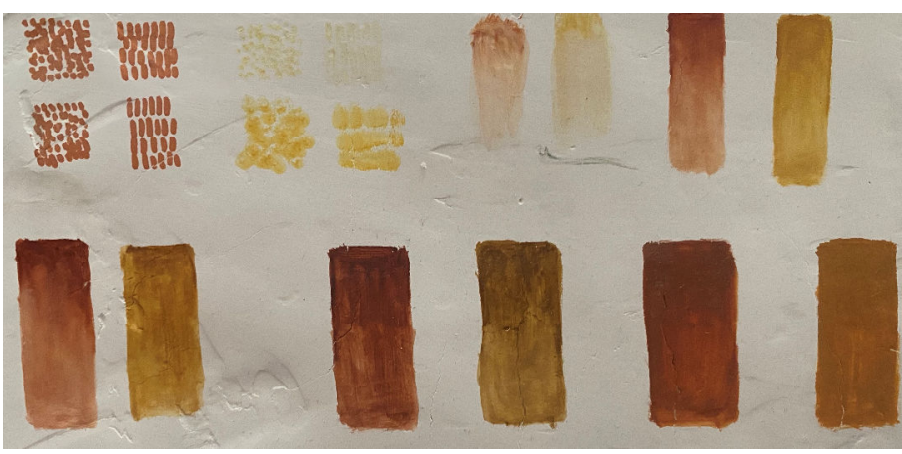

(Çağlar Eryurt, 2020).

\section{Yağlı Boya Tuval Resimlerinde Kullanılan Rötuş Malzemeleri}

Sanayi Devrimi'nden bu yana sanatçılar giderek daha fazla sentetik malzeme kullanmışlar, bireysel araştırmaları benimsemişlerdir. Büyük ölçüde boya maddelerinin yapısını değiştirmeye çalışmış, içeriklerini farklı şekillerde kullanmışlardır (Pentier, 2015, s. 193-195). Bu gelişmeler sonucunda, onarılacak eserlerin geleneksel yöntemler ve malzemeler dışında alternatif yaklaşımlar gerektirdiği ortaya çıkmıştır. Rötuş uygulamalarında kullanılan teknikler ve malzemeler yoğun bir tartışmanın ürünü olarak sürekli değişim-dönüşüm içinde olmuştur. Günümüzde bu çeşitlilik oldukça artmış, uygun malzemeyi bularak yapılan uygulama konusunda yelpaze genişlemiştir. Ülkemizde her malzemeye ulaşma ve uygulama konusunda güçlükler (maliyet, kargo vb. sebeplerle) doğabilmektedir. Bu güçlükler o malzemelerin olmadığı ya da kullanılmadığı anlamına gelmemektedir. Bu konudaki gelişmeleri takip etmek ve malzeme teknolojisi hakkındaki bilgileri güncellemek restoratörler ve konservatörler için işin kaçınılmaz bir parçasıdır.

20. yüzyıla kadarki süreçte sanatçıların kullandıkları pigment-bağlayıcı kombinasyonları daha tahmin edilebilir boyuttayd1. Restorasyon malzemeleri esas olarak egg-tempera, balmumu, tebeşirler ve renkli kalemler gibi kuru malzemeler ile sınırlıydı. Fakat 20. yüzyıl ve sonrası eserlerin malzeme çeşitliliğinde büyük bir artış yaşanmış; organik ve inorganik malzemeler karıştırılmıştır. Özellikle 1950 - 1960'lı yıllar arasında, geleneksel malzemelerin kullanılmasıyla birlikte kararma ve renk değişikliği gibi olumsuz problemlerin ortaya çıkması, konservatörlerin malzemelerle ilgili (Hirci ve Ramovs, 2015, s. 45) bilgi ve geri dönüşümlülüğe olan ilgisinin artmasıla, sentetik ürünlerin kullanımı yaygınlık kazanmıştır (Soltan, 2015, s. 84). Konservatörlerin, ton, doygunluk, parlaklık, doku, pürüzsüzlük, kalınlık ve kırılma indeksini göz önünde bulundurarak, rötuş malzemelerini uygun bir şekilde seçmeleri önemlidir. Bunun için de rötuş malzemeleri konusunda detaylı bilgiye sahip olunması büyük önem arz etmektedir (Bailao ve Cardeira, 2017, s. 249; Digney Peer ve diğerleri, 2013, s. 620).

Rötuş, orijinal boyadan farklı ve daha kolay çözünür bir bağlayıcı ile yapılmalıdır. Uzun ömürlü ve geri dönüşümlülük açısından, sentetik reçineler doğal reçinelerden veya yağ içeren boyalardan daha uygundur. Sentetik reçineler, 20. yüzyılın ikinci yarısında konservatörler tarafından kullanılmak üzere analiz edilmiş ve koruma bilimcileri tarafından incelenen bir dizi ürün koruma amacıyla yaygın olarak kullanılmaya başlanmıştır. Ne kadar karmaşık emülsiyonlar kullanılırsa, rötuşlardaki renk değişikliği o kadar büyük olabilir (Soltan, 2015, s. 83; Nicolaus, 1999, s. 279).

Estetik olarak her duruma uygun ideal, çevresel etkenlere dirençli, kullanımı kolay, uygun çözücülerle çözünen tek bir bağlayıcı bulunmamaktadır. Bu nedenle her durum için rötuş ortamının avantajları ve dezavantajları değerlendirilmelidir. Hazır olarak üretilmiş boyaların dengeli pigment-bağlayıcı oranları, tutarlı ve homojen renk avantajına karşılık ilave hacim arttırıcı, genişletici, seyreltici ve yüzey aktif maddelerin değişikliği gibi dezavantajları bulunmaktadır. Konservatörlerin kendilerinin hazırladığı boyalarda ise, her rötuş alanı için ideal pigment-bağlayıcı oranında hazırlanması olanağı bulunmaktadır. Bununla birlikte farklı pigmentler, uygun doygunluk, dayanıklılık ve uygulama için farklı miktarlarda bağlayıcı gerektirdiğinden, elle karıştırıldığında homojen bir denge sağlamak kolay olmayabilir (Digney Peer ve diğerleri, 2013, s. 620).

Laboratuvar analizleri ile rötuş malzemeleri test edilirken, film oluşturan maddelere dikkat edilmektedir. Bu testler, aynı zamanda bir boya bağlayıcısı olarak da işlem görebilen yüksek kalitede bir vernik arayışı için de gerçekleştirilir. Testlerin amacı, yeni kimyasal ve optik olarak stabil reçineler geliştirmek ve mevcut doğal ve sentetik reçineleri, stabilize etme yöntemini rafine hale getirmektir. Bir boya tabakasının görünümü ve yaşlanmanın ilerlemesi, bir bağlayıcı ve pigmentlerin yanı sıra boyalarda bulunan çözücüler ve yardımcı maddelerden de etkilenebilir. Bu nedenle, ticari boyalar veya pigment ve bağlayıcı karışımları ile yapılan testler bir zorunluluktur. Doğal yaşlanma süresinin uzun olması nedeniyle, hızlı sonuç almak için süreci yapay olarak 
başlatmak gerekir. Hızlandırılmış yaşlanma testleri doğal yaşlanma koşullarını tam olarak yansıtmasa da test edilen malzemelerin direncinin belirlenmesinde doğru bir göstergedir (Szmit Naud, 2003, s. 5). Yağlı boya tuval resimlerinde kullanılan malzemeler yukarıda da belirtildiği gibi çeşitlilik arz etmektedir. Bunlardan yaygın olarak kullanılanlarının başlıcaları aşağıda sıralanmıştır.

\subsection{Geleneksel Yöntemler}

\subsubsection{Egg-Tempera}

Tempera boyama, bilinen en eski resim türlerinden biridir. Batı sanatında gelenek Bizans sanatına ve ikon resmine kadar uzanır ve yumurtanın bir boya bağlayıcısı olarak kullanılması Yunanlılara kadar uzanır. Orta çă̆ İtalyan panel resimlerinin çoğu yumurta tempera ile boyanmış ve yöntem on dördüncü yüzyılda Toskanalı ressam Cennino Cennini tarafından Il libro dell'arte'de yazılmıştır. Tambroni'nin İtalyanca baskısından (1821) Mary P. Merrifield (1844) ve ardından Christiana Herringham (1844) tarafından İngilizce'ye çevrilen Cennino'nun eseri, on dokuzuncu yüzyılda kuzey Avrupa'da tempera tekniğine olan ilginin canlanmasına katkıda bulunmuştur (Massing, 2010, s. 5). Orta Çağ'da İtalyan sanatçılar yumurta sarısını resim bağlayıcısı olarak kullanmışlardır. Yumurta akı ile karıştırıldığında, rötuş için bağlayıcı malzemesi olarak da kullanılabilir. Yumurta sarısı ve yumurta akı karışımı boya ve kuruyan bir yağ veya balmumu ile takviye edilirse ortaya çıkan boyaya egg tempera denmektedir (Nicolaus, 1999, s. 278).

Egg tempera, yıllar öncesine dayanan ve uygulayanın deneyimini gerektiren eski bir rötuş tekniğidir. 19. yüzyıl restorasyon uygulamalarında daha sık belgelenmeye başlamıştır (Nicolaus, 1999, s. 278). Egg-temperanın uygulaması oldukça karışık ve çok aşamalı bir tekniktir. Birkaç kat halinde yapılır ve her uygulamadan sonra kuruması beklenir. İnce ve opak katmanların rötuşu için idealdir. Kuruduktan ve verniklendikten sonra önemli bir renk değişikliğine uğrar, ancak zaman içinde iyi renk kararlılığına sahip olduğu düşünülmektedir. Vermilyon ve kadmiyum sülfürler de dahil olmak üzere bazı kükürt içeren pigmentlerle uyumsuzdur. Dezavantajlarından biri, özellikle sadece yumurta sarısı kullanıldığında zamanla birçok çözücüye karşı önemli bir direnç geliştirebilmesidir. Yumurta beyazı ve/veya balmumu katkısı çözünürlüğünü arttırmaktadır. Daha sonra çıkarmayı kolaylaştırmak için her zaman bir ön izolasyon verniği tavsiye edilmektedir (Digney Peer ve diğerleri, 2013, s. 627; Nicolaus, 1999, s. 278).

19. yüzyılda Almanya'da birçok resim restoratörü tarafından Egg-tempera tekniğiyle rötuş yapıldığ belgelenmiştir. Berlin'deki Kaiser Friedrich Müzesi geliştirilmiş, sonrasında Avrupa'daki birçok müzede (Londra, Ulusal Galeri; Belçika, Hollanda) ve Amerika'da yoğun olarak kullanılmıştır. Çoğu durumda, hızlı bir şekilde kuruduğu ve renk değişikliğine karşı dayanıklı olduğu için yağlı boyadan su bazlı boyalara kadar uygun bir kullanım sağladığ 1 için tercih edilmiştir. 20. yüzyılın ortalarından sonra, kararlı yapıdaki ve suluboya kadar kullanımı kolay ancak daha güvenilir (suluboya higroskopik ve nemdeki değişikliklere duyarlı yapıdadır) sentetik reçineler geliştirilmiştir. Bununla birlikte egg tempera ile rötuş tekniğinin kullanımı azalmıştır (Kempski, 2010, s. 36-37; Massing, 2010, s. 5-17).

\subsubsection{Yă̆ (Keten Tohumu Yă̆g, Haşhaş Yă̆̆, Ceviz, Yă̆ı, Sanatçıların Yă̆glı Boyaları)}

Orijinal yağlı boyaların rengini ve dokusunu yağlı rötuş boyaları ile eşleştirmek, rötuşu orijinal boyadan ayırmanın sorunlu olması dışında, nispeten basit bir işlemdir. Yağlı rötuşların başlangıçta optik özellikleri tatmin edici olsa da yağlı boyaların hızlı yaşlanma özellikleri günümüzde rötuş için problemli olarak kabul edilmektedir. Zamanla bu boyalar önemli ölçüde renk değiştirir ve orijinal boyayı etkilemeden çıkarılması zor ya da imkânsız hale gelebilir. Yağlı boyanın yavaş kuruma özelliği, her katmanın bir sonrakini uygulamadan bir ya da iki gün kuruma beklemesi gerektirdiğinden rötuşu zaman alıcı bir işlem haline getirir (Digney Peer ve diğerleri, 2013, s. 627). Daha yavaş kurumaya rağmen, ceviz ve haşhaş yağı daha açık renklerin üretmesine izin vermesi ve düşük sararma özelliği nedeniyle bazen rötuş çalışmaları için tercih edilir. Fakat özellikle haşhaş yağının erken kırışıklık göstermesi kullanım tercihini düşürmektedir (Nicolaus, 1999, s. 273-274).

\subsubsection{Doğal Reçineler (Mastik, Dammar, Kopal, Sandarac, Maimeri Restorasyon Boyaları)}

Doğal reçine boyaları organik çözücülerde çözünür ve yağa bağlı boyalardan önemli ölçüde daha hızlı kurur ve daha hızlı bir çalışma süreci sağlar. Kuruyan yağlara ve su bağlayıcı maddelere göre daha yüksek bir kırılma indisine sahiptir. (Nicolaus, 1999, s. 276). Bununla birlikte, bu reçineler önemli ölçüde sararır, koyulaşır ve çözücüye oldukça dirençli hale gelir. Balmumu ilavesi kullanım özelliklerini iyileştirir, parlaklığı azaltır ve potansiyel olarak daha kolay çıkarmaya izin verir. Günümüzde nadiren dammar veya mastik gibi doğal reçineler rötuş için kullanılmaktadır (Hirci ve Ramovs, 2015, s. 45). Doğal reçine boyalarının kullanımının büyük ölçüde $A B D$ ve İngiltere'de sentetik reçineler ile yer değiştirdiği, buna karşın birçok Avrupa ülkesinde devam ettiği izlenmektedir (Digney Peer ve diğerleri, 2013, s. 627).

Mastik esaslı Maimeri restorasyon boyaları, çoğunlukla palette yeniden çözülmedeki güçlük ve boya katmanlarının yetersiz parlaklığına ilişkin bazı çekincelere rağmen daha uzun süredir kullanılmaktadır. Yaşlanma 
testlerinde, renklerin parlaklık kaybetme eğilimi doğrulanmış, ancak olumlu olarak raporlanmışlardır. Muhtemelen $\alpha$-pinen (terebentin yağından daha saf) olan bir çözücüdeki mastik reçinenin yanı sıra, bu boyalar alüminyum sabunlar, silika, killer ve muhtemelen balmumu gibi stabilizatörler içerirler. Maimeri restorasyon boyalar1, Paraloid B72, PVA, RestaurArte konservasyon boyalar1, Golden MSA konservasyon boyalar1, Rembrandt suluboyaları gibi rötuş malzemeleri seçilerek, hızlandırılmış ışık yaşlandırmasının öncesi ve sonrası malzemelerin kullanım ve optik özellikleri analiz edilmiştir. Testler karşılaştırılmalı olarak görsel inceleme ve enstrümantal analize tabi tutulmuştur (Szmit Naud, 2003, s. 6).

\subsubsection{Yă̆ Reçineler (Schmincke Mussini Reçine Yă̆ı Renkleri)}

Yağlı reçine karışımları, yağlı boyalardan daha hızlı kuruma hızına ve doğal reçineye bağlı boyalardan daha fazla elastikliğe sahip boyalar oluşturmak için kullanılır. Yağlı reçine boyalar, daha opak rötuş katmanlarının üzerine yapılan vernikleme için yaygın olarak kullanılır. Bu boyalar, yağlı boyaların dezavantajlarını paylaşır, belirgin bir şekilde renk değiştirir ve polar çözücüler kullanmadan çözünmeleri zorlaşır (Digney Peer ve diğerleri, 2013, s. 628; Nicolaus, 1999, s. 276).

\subsubsection{Mumlar (Doğal Balmumu: Balmumu, Karnauba; Sentetik Mum: Parafin, Mikrokristalin Mum, Mineral Mum, Kozmolloid)}

Doğal balmumu, 2000 yılı aşkın bir süredir Ankostik (Encaustic) boyalar için bağlayıcı olarak kullanılmaktadır. Mumlar su tutmaz, termoplastiktir; düşük aromatik organik çözücülerde çözülebilir ve saten-mat bir görünüme sahiptir. Yirminci yüzyılın başlarında kullanılan balmumu-reçine rötuş karışımları, örneğin balmumu-dammarı içerir. Balmumu içerikli rötuşun bir dezavantajı, firça ile uygulamayı güçleştirmektedir. Balmumu rötuşunun üzerine uygulanan vernik bir püskürtme tabancası ile uygulanmalıdır (Digney Peer ve diğerleri, 2013, s. 628).

\subsubsection{Solvent Bazlı Rötuş Boyaları}

Bu tür boyalar; Akrilik (Paraloid B72, Paraloid B67) reçineler, Magna Renkleri (Paraloid F10), Keton reçineleri (Laropal K80), Polioksazolin (Aquazol, PEOX), PVA (AYAA, AYABi AYAC, AYAT, Mowilith 20, Lascaux Rötuş Medyumları), Polivinil Alkol (Mowiol), Üre Aldehit (Laropal A81, Gamblin Konservasyon Boyaları) olarak sıralanabilir. Yaklaşık 1930'dan beri, bilim adamları ve restoratörler rötuşlara uygun bağlayıcı malzeme bulmak için sentetik reçinelerle deneyler yapmışlardır. Selüloz eterler, akrilik reçineler, polivinil asetat, polivinil alkol, polisikloheksanon reçineleri (keton reçineleri) ve alkid reçineleri ile çalışmışlardır (Nicolaus, 1999, s. 281).

Akrilik reçineler, ABD'de 1930'ların başlarında, yani restorasyon literatüründe ilk olarak belirtilmelerinden yirmi yıl önce vernik olarak kullanılmıştır. Akrilik reçinelerin kalıcılığı kimyasal yapılarına bağlıdır. Etil akrilat ve metil akrilat, daha kararlı akrilik reçinelerden ikisi olmakla birlikte, White Spirit içinde çözülebilen butil metil akrilat, sarı olabilir ve 1şıkta çözünmez hale gelebilir. Akrilik reçinelerin görsel nitelikleri, doğal reçineler ve polisikloheksanon reçinesi kadar iyi değildir. Bununla birlikte, iyi mekanik özelliklere ve stabiliteye sahiptirler. $\mathrm{Su}$, white spirit veya terebentin ile seyreltilebilir, daha sonra suluboya, sıcaklık veya yağ rötuşları gibi uygulanabilirler. Rötuşlarda kullanıldığında, akrilik reçine boyaları nispeten hızlı bir şekilde kurur, bu da ayrı katmanların aralarında uzun aralıklar olmadan birbirinin üzerine uygulanabilmesi avantajına sahip bir özelliktir. Dezavantajı, akrilik boyaların palette nispeten hızlı bir şekilde kurumasıdır. Empresyonist ve Ekspresyonist yağlı boya tablolarının belirgin firça darbeli yapıları, akrilik reçine boyalarıyla rötuşlanabilmektedir (Nicolaus, 1999, s. 281-282).

En yaygın olarak kullanılan rötuş reçineleri, aynı zamanda koruma dereceli resim vernikleri olarak kullanılan reçinelerle yakından ilişkili veya (başlangıçta özdeş) reçinelerle yakından ilişkili olan sentetik doğrusal polimerler veya düşük moleküler ağırlıklı sentetik oligomerlerdir (Bucklow, 2010, s. 62). Solvent bazlı akrilik boyalar çok çabuk kurur, ancak çözücü seyreltici içinde çözünür kaldığında, aşağıdaki katmanları almadan veya bozmadan ardışık katmanları uygulamak zordur. Nispeten kararlıdırlar, vernik sonrası renk tonunda hafif bir değişim gösterirler. Akrilik emülsiyon boyalardan daha kırılgandırlar. Parlaklığı ve yarı saydamlığı arttırmak için başka bağlayıcılar ilave edilebilir (Digney Peer ve diğerleri, 2013, s. 624).

Akrilik reçine Paraloid B72, İngiltere'deki konservatörler tarafından 1960'larda (Ackroyd, 2010, s. 51) kullanılmaya başlanmış; 1980'lerden bu yana kullanımı popülerleşmiştir (Szmit Naud, 2003, s. 6). Paraloid B67 de (Nicolaus, 1999, s. 281) yağlı boya rötuşları için kullanılmıştır. Kimyasal stabilitesi yüksektir ve kolayca geri dönüşümlü, renk değiştirmeyen bir ortam sağlar. Ana dezavantajları, normalde çözündüğü hidrokarbon çözücülerin potansiyel toksisitesi, pigmentlerin ortam içinde yetersiz, eşit dağılmaması (Dunkerton, 2010, s. 93) ve buharlaşma hızıdır. Bu, Paraloid B72 ile yapılan boyaların uygulamada kullanım ve bakım konusunda dikkatli olunması gerektiği anlamına gelir. \%20-30'luk bir çözelti (toluen ve ksilen içinde Paraloid B72; White Spirit içinde Paraloid B67), doymuş bir yağlı boyayı eşleştirmek için yararlı bir rötuş ortamı sağlar. Bununla birlikte, rötuşlanacak yüzey görünüşte mat ise, \%5'in altında bir reçine / çözücü çözeltisi daha uygun bir sonuç verebilir (Lowry, 2010, s. 87; Nicolaus, 1999, s. 282; Szmit Naud, 2003, s. 8). Paraloid B72'nin rötuşlama ortamı olarak 
kullanılmasının birçok faydası vardır. Uzun vadede düşük değerli hidrokarbon çözücüler kullanılarak kolayca çözünür, böylece gerekirse rötuş kolayca çıkarılabilir; rötuşlar yaşlandıkça renk değiştirmez. Bununla birlikte, bağlayıcıdaki hacim küçülmesi sadece B72'yi kullanarak firça darbeleri ve koyu renk boyaları çoğaltmanın kolay olmadığı anlamına gelir; bu tür dokuların altta yatan dolgulara dahil edilmesi gerekir (Lowry, 2010, s. 91). Bu renkler, verniklenmemiş temperalarda, akrilik bağlayıcının gerekli olduğu durumlarda kullanılmaktadır (Bestetti ve Saccani, 2014, s. 31).

Keton (Polisikloheksanon) reçineleri, 1960'lardan beri hem vernik hem de bağlayıcı olarak korumada kullanılmaktadır. Reçinelerin kimyasal yapıları oldukça karmaşıktır ve hala tam olarak bilinememektedir. $>\% 30$ aromatik hidrokarbon çözücüler içinde çözünür, ancak yaşlanma sırasında grimsi bir tona dönüşebilir, geri alınması için daha güçlü bir çözücü gerekmektedir. Saf keton reçine boyaları ticari olarak mevcut değildir, konservatörler tarafından hazırlanmalıdır. Keton reçinelerinin kuruma süreleri nispeten kısa olduğundan, çok hızlı bir şekilde rötuş katmanları oluşturmaktadır. Dezavantajlarından birkaçı, kuruduktan sonra çok esnek olmayan, kırılgan bir film oluştururlar, bir süre sonra çözünmesi zorlaşır ve mekanik strese maruz kalırsa boya tabakasının yüzeyinden soyulma eğilimi gösterirler (Digney Peer ve diğerleri, 2013, s. 624; Nicolaus, 1999, s. 283).

Polioksazolin, dört molekül ağırlık aralığında (5K, 50K, 200K, 500K) mevcuttur. Bir dizi polar çözücüde (su, ethanol, aseton) çözünür. Aquazol, akrilik boyaların yanı sıra yüksek balmumu içeriğine sahip yüzeylerin rötuşlanmasında, geri dönüşümlü ve uygun malzemelerden biridir (Digney Peer ve diğerleri, 2013, s. 624).

Polivinil Asetatlar, 1930'ların ortalarında yüzey kaplama ve konsolidasyon malzemesi olarak kullanılmıştır. 1935 yılında çözelti ve dispersiyonlarda polivinil asetat ile rötuşlamada ilk denemeler gerçekleştirilmiştir. 1950'den sonra rötuş medyumu (Bakalit AYAB) olarak boya hazırlanmasında kullanılmaya başlanmıştır. Çeşitli PVAC ürünlerinin özellikleri önemli ölçüde değişmektedir, ancak bunların dayanıklılıkları hakkında henüz çok az şey bilinmektedir. PVA boyalar, renk değişimine karşı dirençli, zaman içinde düşük toksiteli çözücü ile kolayca çıkarılabilir özelliktedir. Seyrelticiye daha yavaş buharlaşan çözücüler eklenirse, makul bir çalışma süresi sunmaktadır. Siyah pigmentler PVA ortamında hafif gri görünebilir. Almanya'da mevcut PVAC reçinelerinden Mowilith 20 kullanılır. Etanol içinde çözündürülür ve eğer uygunda, etilen glikol monoetil eter palette hızlı kurumaması için eklenebilir (Digney Peer ve diğerleri, 2013, s. 624; Nicolaus, 1999, s. 283; Szmit Naud, 2003 , s. $6)$.

Polivinil Alkol reçineleri, ışığa dayanıklıdır ve nispeten mattır. Bununla birlikte yüksek derecede reaktif hidroksil gruplarına bağlı çapraz bağlanma, birçok çözücüye ve yaşlanmaya karşı dirençli ve geri dönüşümlülüğü zor veya imkânsız hale getiren film tabakasıyla sonuçlanır. Mowiol, nemi emebilir ve aynı zamanda yüksek bir kopma mukavemetine sahipken iyi gerilebilir, pigmentleri güvenli bir şekilde bağlar. Mat boya yüzeylerinin rötuşu için parlak bir görüntü sağlar ve bu yüzeyler için tercih edilmez (Digney Peer ve diğerleri, 2013, s. 624; Nicolaus, 1999, s. 283).

Laropal A81, optik özellikleri doğal reçinelere benzeyen, düşük molekül ağırlığına sahip (Hirci ve Ramovs, 2015, s. 47) az miktarda aromatik ile alifatik hidrokarbon çözücülerin karışımından esterlere (Butil Asetat), aseton ve etanole kadar çok çeşitli çözücüler içinde çözünür. Reçine, White Spirit D40 gibi alifatik hidrokarbonlarda da çözünür hale gelebilir. Bununla birlikte bu çözeltiler kararlı değildir ve reçine çökme eğilimindedir. Bu ideal olmayan durum, rötuş renkleri üretmek için, yüksek konsantre reçine çözeltisi elde etmek için yararlıdır; yüksek oranda bağlayıcı parlak ve yoğun renkler anlamına gelmektedir. Genellikle katmanlı ve yarı saydam yüzeyler oluşturmak için guaj üzerinde de kullanılır.

Gamblin Konservasyon Boyaları, 1990’ların sonlarında (Ackroyd, 2010, s. 51) koruma için özel olarak üre aldehit reçineye dayanan boyalar formüle edilmiş; doğal reçine boyalarına benzer işleme özelliklerine sahip dayanıklı, geri dönüşümlü ve kararlı 1şık haslığı bir sentetik reçine arayan konservatörler tarafından üretilmiştir (Soltan, 2015, s. 84). Renkler yumuşatılarak kullanımdan önce çözücülerle ıslatılabilir; bu amaçla az miktarda ve diğer malzemelerle etkileşiminden kaçınarak seçilmelidir (Bestetti ve Saccani, 2014, s. 28-29; Digney Peer ve diğerleri, 2013, s. 624). Kullanımdan önce, bağlayıcının eşit bir şekilde dağılması için karıştırılmalıdır. Daha fazla verimlilik ve kolay çalışma elde etmek için, paletteki boya kurutulur, çözücünün buharlaşması beklenir. Kullanımı pratiktir. Üst üste uygulanan renk katmanları çözünmez. Yarı saydam veya opak renkler elde edilebilir. Kullanılan farklı çözücüler ile rengin parlaklığı değiştirilebilir, bu önemli bir avantajdır (Hirci ve Ramovs, 2015, s. 47-52; Dunkerton, 2010, s. 94-100).

Regalgez 1094, düşük polaritesi sebebiyle, pigmentler gibi yüksek polar veya iyonik bileşiklerle kararlı bir karışım konusunda sınırlandırılmaktadır. Bu nedenle çok sık kullanılmamaktadır. İtalya' da yaygın olarak kullanılan tarama tekniği için tercih edilmektedir. Bu renkler, çağdaş resimlerdeki monokromlar veya zemin boyama için kullanılabilmektedir. Rötuş işlemlerinden sonra vernik gerektirmeyen mat sanat eserleri için uygundur (Bestetti ve Saccani, 2014, s. 31). 
Düşük kırılma indisine sahip reçineler (Mowilith 20 ve Paraloid B72), yüksek kırılma indisine sahip reçinelere (Laropal K80, Regalrez 1094 ve MS2A) göre inorganik pigmentlerle daha opak boyalar üretmektedir. Yüksek kırılganlık reçinesi, düşük kırılganlık reçinelerine göre inorganik pigmentlerle daha şeffaf sırlar vermektedir. Organik pigmentlerin yeterince dağılmaması nedeniyle organik pigmentlerle vernikleme için, polar çözücülerdeki Paraloid B72 ve Mowilith 20 kadar etkili değildirler. Organik pigmentlerin yayılması ve renk gelişimi için, polar çözücülerdeki Mowilith 20 ve Paraloid B72 çözeltilerinin, polar olmayan çözücülerdeki Laropal K80, Regalrez 1094, MS2A ve Laropal A81 çözeltilerinden çok daha iyi rötuş bağlayıcısı olduğu kanıtlanmıştır. Bir çözücünün polaritesi, organik pigmentlerin dağılmasında belirleyici bir faktör olduğundan, ksilen veya Shellsol A100 gibi polar olmayan çözücülerde organik pigmentlerin Paraloid B72 çözeltileri ile iyi bir şekilde dağılması beklenemez. Bazı organik pigmentleri temel alarak, sanatçıların ve endüstriyel boyaların renklerinin eşleştirilmesinde polar olmayan çözücülerdeki rötuş ortamıyla asla elde edilemeyeceği oldukça açıktır (Koneczny, 2010a, s. 72-73). Rötuş için yeni malzemelerin geliştirilmesi, aydınlatma ve 1ş1k denetimi, 1960'lardan itibaren galeri ve müzelerdeki iklimlendirme kurulumu gibi önlemler restorasyonların ömrünü önemli ölçüde artırmış ve resimlerin yeniden restorasyonu ihtiyacını azaltmıştır (Ackroyd, 2010, s. 51).

\subsubsection{Emülsiyon Rötuş Boyalart (Akrilik Emülsiyonlar (Liquitex, Altın Talens, Winsor\&Newton, Daler- Rowney) ve PVA Emülsiyon Boyalar (LeFranc-Bourgeois Flashe, Grumbacher Hyplar Sanatç Renkleri)}

Homojenlik ve sanatçı kullanım kolaylığı için üretilen akrilik emülsiyon boyalar genellikle stabildir ve iyi çalışma özelliklerine sahiptir. Bununla birlikte, bunlar genellikle bağlayıcı bakımından çok zengindir, katkı maddeleri ve hacim arttırıcılar içerebilir. Geleneksel olarak formüle edilmiş akrilik boyalar, eskimiş boya filmlerinin yanı sıra doğal reçine bazlı boyaları taklit etmeyen biraz yă̆ ve plastik etkili bir görünüme sahiptir. Alternatif olarak, "yüksek yüklü" emülsiyon akrilikleri, daha yüksek pigment içeriği sağlar ve geleneksel yağlı boyaya daha benzer bir görünümde boya filmleri verir. Yüksek yüklü akrilikler, yüksek pigment içeriğine sahip boyalardır. Zengin renkli zemin veya gesso olarak veya ince uygulamalar için son derece güçlü bir boya olarak kullanılabilirler. Tek bir pigmentten üretilerek onlara çok zengin ve yoğun bir görünüm verirler. Guaja benzer bir görünüme sahiptirler, ancak kuruduğunda çözünmezler (Goldenpaints, t.y., para. 1).

Ticari olarak hazırlanan akrilik emülsiyon boyalar su ile seyreltilebilir ve uygulanabilir; bu özellik, koruma atölyelerinde çözücüye maruz kalma süresini giderek daha fazla sınırlamak isteyen birçok konservatörün takdir ettiği bir özelliktir. Kuruduktan sonra, bu boyalar suda kolayca çözünmez, bu da kolay tabakalanmaya izin verir, ancak geri alınması için aromatik hidrokarbon çözücüler gerektirir. Akrilik emülsiyon boyaları çok çabuk kuruduğundan, münferit boya tabakaları hızla uygulanabilir. Hızlı kuruma oranının dezavantajı, boyaların palet üzerinde çok hızlı kurumasıdır; bununla birlikte, çalışma süresini uzatmak için kuruma geciktiricileri ticari olarak temin edilebilir. Akrilik emülsiyon boyalar iyi kaplama gücüne sahiptir, ancak kuruduktan sonra ve verniklendiklerinde önemli renk değişimleri gösterebilirler.

Akrilik emülsiyon boyalar ayrıca ıslatıcı ajanlar, yüzey aktif maddeler ve genişleticiler gibi bir kısmı eskiyen boya filminin yüzeyine geçebilen yüzey parlaklığında bir azalmaya ve kir toplama eğiliminde artışa neden olan çok sayıda katkı maddesi içerir; ancak bu biraz boya kalitesine bağlıdır. Bu boyalar, mükemmel 1şığa dayanıklı organik pigmentler ve az sayıda geleneksel pigment içerir. Polivinil asetat reçinesi temel olarak solvent bazlı sistemlerde koruma amaciyla kullanılırken, reçine ticari olarak suda çözünür emülsiyon boyaları hazırlamak için de kullanılmıştır. Bu polimer renkleri akrilik emülsiyon boyalarına benzer şekilde işlemektedir, suda çözünmeyen sert bir film oluşturmak için çabuk kurumaktadırlar (Digney Peer ve diğerleri, 2013, s. 625).

\subsubsection{Su Bazlı Rötuş Boyaları (Gum Arabic-Gum Senegal, Guaş Boyalar, Suluboya Çubuklar-Markörler, Selüloz Eterler (Metil Selüloz, Klucel E, Aquacel, Tylose MHB 1000), Nişasta (Jun Funori)}

Koruma alanında "geri dönüşümlü” oldukları için çok yaygındırlar, literatürde pigmentlerle karıştırıldığında yaşlanma sırasındaki stabiliteleri hakkında kapsamlı bir çalışma bulunmamaktadır. Suluboya, 1980’lerin başlarından itibaren, yağlı boyaların rötuşları için Polonya' da popüler hale getirilmiştir (Szmit Naud, 2003, s. 6). Ticari renklerin sadece Gum Arabic (Arap zamkı) içermediği, kitre ve bağlayıcının kararlılık ve çözünürlük gibi özelliklerini değiştirebilecek katkı maddeleri de içerdiği bilinmektedir. Sulu boyalar büyük ölçüde ince taneli pigmentlerden oluşur (Nicolaus, 1999, s. 277). Sulu boyaların renkleri, kurutma ve/veya vernikleme sirasında değişebilir, tekniği uygulamadan önce deneyim gerektirmektedir. Tüp sulu boyaların kullanımı ve uygulaması daha rahattır. Ama macun benzeri bir formda uygulanmaları, kurudukça çatlamalarına sebep olabilir. Sulu boya pigmentleri ışı̆̆a, yağlı veya guaj boyalarda kullanılan pigmentlerden daha duyarlıdırlar (Digney Peer ve diğerleri, 2013, s. 625; Nicolaus, 1999, s. 277-278).

Guaj boyalar, suluboyaların "beyaz tutkal” boyalarla karışımından oluşan, günümüzde barit veya alüminyum oksit gibi dolgu maddelerini de içeren boyalardır. Rötuş tekniği karmaşıktır. Sadece rengi ve formu değil, aynı zamanda boya tabakasının yapılarını da uygulamak mümkündür. Guaş boyaların içeriğinde dolgu malzemeleri ve beyaz pigmentler bulunduğu için mat ve opaktırlar. Opaklığın gerekli olduğu durumlarda sulu boyalardan daha 
uygundurlar. Bununla birlikte kalın guaş katmanları çatlama eğilimindedir. Kuruduktan sonra renkler daha açık hale gelir, verniklemeden sonra koyulaşırlar (Digney Peer ve diğerleri, 2013, s. 625; Nicolaus, 1999, s. 278).

Gum Arabic (Arap zamkı), kırılgandır ve kolayca çatlar, bunun için plastikleştiriciler (geleneksel olarak bal) kullanılmıştır, renkleri rötuşlamak için düşük oranda Gliserol kullanılmaktadır.

Aquazol (Poli-2-Etil-2-Oksazolin veya PEOX), Richard Wolbers tarafindan tanitılan bu polimer, aslında konsolidasyon ve dolgu malzemelerinin hazırlanması için kullanılmıştır. Suda tam çözünür, farklı molekül ağırlıklarda (50-200-500) bulunmaktadır. Geniş bir çözünürlüğe sahiptir (su, alkol ve keton içinde). Yüksek termal ve kimyasal kararlılığı ile akrilik resimlerde rötuş için uygundur (Bestetti ve Saccani, 2014, s. 31-32).

Suluboya markörleri, ince ve kalın olarak iki farklı firça uç seçeneği bulunan sanatsal materyal olarak sıkça kullanılan suluboya çeşitlerinden biridir. Rötuş için kullanımıyla ilgili çok veri bulunmamaktadır. Sadece bir araştırmada (Cardeira ve diğerleri, 2017, s. 88-96), üç farklı rötuş tekniği, üç farklı dolgu malzemesi üzerinde denenmiş, renk yayılımı, uygulaması, kademeli renk oluşturma kabiliyetleri karşılaştırılmıştır. En iyi sonuç veren rötuş tekniğinin pointilizm (noktacılık) ve dolgu malzemesinin kalsiyum karbonat olduğu gözlemlenmiştir. Özellikle küçük kayıplar için kullanımının mümkün olduğu düşünülmektedir.

Selüloz Eterler, çeşitli viskoziteleri, çözünürlükleri ve parlaklık seviyeleri bulunan, su ile kolayca geri dönüşümlülüğü sağlanan malzemelerdir. Ham tuval üzerindeki lekeleri rötuşlamak için metil selüloz tozları kullanılabilmektedir. Bununla birlikte, havadaki kirleticilerin emilmesi nedeniyle renk değişikliği oluşabilmekte; yoğun 1şık altında fotokimyasal reaksiyon sebebiyle parçalanabilmektedirler (Digney Peer ve diğerleri, 2013, s. 626; Nicolaus, 1999, s. 281).

Jun Funori, Japon deniz yosunu nişasta özünden yapılmaktadır. Kuru pigmentlerle karıştırıldığında, çok mat boya sağlayan Jun Funori, çok mat yüzeyler için özellikle modern çalışmalarda kullanılır; küf oluşumuna karşı hassas, zamanla sarama eğilimindedir (Digney Peer ve diğerleri, 2013, s. 626).

Kordofan, Gum Arabic ve öküz safrası ile formüle edilmiş suda tamamen çözünür ve geri dönüşümlü bir malzeme olan Schmincke Horadam (Fernandez Villa, 2015, s. 203) sulu boya ile yapılan uygulamalarda sıç̧a tercih edilmektedir.

\subsubsection{Kuru Boyalar (Renkli Kalemler, Pastel Boyalar)}

Bazı durumlarda, bir kuru boyama tekniği ile rötuşlama, sıvı bir boya yerine tercih edilebilir veya boya bazlı rötuş için uygun bir tamamlayıcı olabilir. Kuru boyama, bütün kayıpları tasarıma yerleştirmek, mat ve alt boyayı rötuşlamak veya tuval örgüsü boyunca sürtünme rengi vermek gibi farklı görsel efektler oluşturmak için yararlıdır. Kullanılan pigmentler genellikle üretici tarafından tanımlanmaz ve birçoğu organik kökenlidir ve solmaya karşı hassastır. Renkli kalemler, genellikle sakız, sentetik reçine ve balmumuna bağlı pigment veya boyaların bir çekirdeği ile doldurulmuş ahşap veya kâğıt tüplerdir. Birçok renk 1şığa dayanıklı olmayan organik boyalar içerir.

Pasteller, kitre zamkı veya metil selüloz gibi az miktarda su bazlı bir bağlayıcı ile karıştırılmış ince ögütülmüş pigmentlerden yapılmış yumuşak, bükülebilir boya kalemleridir. Açık renkler, mineral esaslı dolgu maddeleri (tebeşir, jips, talk, kaolin vb.) ile seyreltilmiş güçlü pigmentlerden oluşur. Pasteller tozlanma ve kolayca lekelenme eğilimindedir, gevşek bağlı pigment kolayca çıkarılır veya diğer yüzeylere aktarılır. Daha mat bir görünüm elde etmek için sulu boyalara zemin pastelleri eklenebilir. Pasteller kolayca yapılır ve konservatörün belirli tonları ve doygunluk derecelerini elde etmesini sağlar (Digney Peer ve diğerleri, 2013, s. 626).

\subsubsection{Tek Aşamalı Rötuş (Yapısal Rötuş) Săğlayan Malzemeler (B72 Rötuş Jelleri, Pigmentli Balmumu Reçine Çubuklart (Gamblin Pigmented Wax/Resin)}

"Yapısal rötuş" (Pentier, 2015, s. 191), olarak adlandırılan bu sistemde tek aşamada boşluğun (lakunanın) dolgusu, dokusu ve renkleri tamamlanır. Yüzey dolgu ve dokusunun yapılandırılarak renklendirmenin ikinci aşamada yapıldığı rötuş yönteminin aksine, bu yöntemde dolgu, doku, renk ve iç yapı aynı anda eşleştirilir. Yapısal rötuş genellikle illüzyonist rötuşla sınırlıdır. Yapısal rötuş yenilikçi bir tekniktir ancak kendi sınırları vardır: "geleneksel” rötuş yöntemlerinin yerini almayı değil onları tamamlamayı amaçlar (Pentier, 2015, s. 206).

B72 rötuş jelleri, 2007 yılında İngiliz restoratör Peter Koneczny tarafından herhangi bir koyulaştırıcı eklemeden Paraloid B72 (Acryloid B72) reçinesinden sekiz saydam jel geliştirilmiş, 2010 yılında ticarileştirilmiştir. Her jelin özellikleri Paraloid B72 konsantrasyonuna, çözücünün uçuculuğuna ve moleküllerin organizasyon derecesine göre değişir. Farklı kıvam, kuruma süresi, parlaklık ve yüzey dokusu gibi kullanım özellikleri vardır. Bu jellerin özelliklerinin genişletilmesi için, sekiz jelden ikisine füme silika eklenmiştir. Jellerin, sadece pigmentli reçine çözeltisinin kullanılmasıyla istenen boya özelliklerine kolayca erişilemediği durumlarda kullanılması amaçlanmıştır (Koneczny, 2010b, s. 142; Pentier, 2015, s. 197). Farklı buharlaşma hızına sahip üç çözücü kullanılır: Dowanol PM, Dowanol PnP ve Dowanol DPM. Farklı kurutma sürelerine sahip jel veya jel karışımı seçimi, rötuşun ölçeğine ve karmaşıklığına bağlıdır (Koneczny, 2010b, s. 143). 
Yapılan testler sonucunda, jellerin ışık kararlılığı iyidir ancak fiyatları ve kuruma büzülmeleri yüksektir. Farklı görsel efektler (mat, parlak, opak ve şeffaf) üretilebilir; kullanıma hazır ve kolaydır. Kuruma aşamasında pigmentlerin renkleri değişmemektedir. Bazı jellerin hızlı kuruma süreleri sebebiyle pigment öğütmeyi zorlaştırmaktadır. Küçük-büyük boşluk alanlar, koyu renk boya alanları, şeffaf ve koyu boya rötuşları, bakır boyalarla yapılmış yağlı boyalar için kullanılmaktadır (Pentier, 2015, s. 205-206).

Pigmentli Balmumu-Reçine çubukları, resimlerde kayıpları doldurmak için orta derecede 1sıltılmış sıcak spatül ile eritilerek yüzeye uygulanmaktadır. İçeriğinde, balmumu, mikrokristalin balmumu, Laropal A81 ve 1şığa dayanıklı pigmentler bulunmaktadır. Bu balmumu-reçine çubukları, Buffalo State College Sanat Koruma Bölümü tarafından geliştirilmiştir (Gamblin, t.y., para. 1). Boyaya veya alt boyamaya uygun 12 renk (nötr baz, titanyum beyazı, titanyum devetüyü rengi, orta değer gri, fildişi siyah, sarı okra, ham sienna, ham ombra, yanmış ombra, Venedik kırmızısı, orta değer mavi, krom oksit yeşil) bulunmaktadır. Ayrıca fotoğraf restorasyonu için geliştirilmiş 14 nötr gri rengin bulunduğu set bulunmaktadır. Kolayca şekillendirilerek doku verilebilirler, neme dayanıklıdır ve belirsiz raf ömrü vardır. Geri dönüşümlülüğü nispeten kolaydır. Renkler birbirleriyle karıştırılabilir, boyama ve verniği kolayca kabul etmektedir. Konuyla ilgili araştırmanın yapıldığı "Development of a Pigmented Wax/Resin Fill Formulation for the Conservation of Paintings" projesi 2011 y1linda Christine McIntyre tarafindan sunulmuştur (McIntyre, 2011). Renkli dolguların dezavantajı, kurutma işlemi sırasında meydana gelen yüksek renk değişikliğidir. Bu nedenle, rötuş sırasında renkli dolgu numuneleri sadece 1slak değil, kuru olduklarında da orijinal boya alanıyla karşılaştırılmalıdır (Fernandez Villa, 2015, s. 207).

\subsection{Ham Sienna (Raw Sienna)-Yanmış Sienna (Burnt Sienna) Pigmentleri}

Pigmentler organik ve inorganik olarak ikiye ayrılmaktadır. İnorganik pigmentler toprak çökeltilerinden (okr, sienna gibi), minerallerden (zincifre gibi), islenmiş metalik bileşiklerden (kurşun beyazı gibi) ve erimiş metalik bileşiklerden (kobalt mavisi gibi) oluşabilmektedir. Organik pigmentler ise hayvanlardan (kemik siyahı gibi), bitkilerden (madder lakı gibi) ya da bitki özünün sentetik işlemden geçmesiyle (alizarin kırmızısı gibi) oluşabilmektedir (Seymour, 2003, s. 22-23). Organik pigmentler, Kadmiyum pigmentleri gibi yüksek boyama ve gizleme gücü olan veya toprak pigmentleri gibi düşük boyama ve gizleme gücüne sahip inorganik pigmentlerin aksine, yüksek boyama gücüne sahiptir ve iyi bir şeffaflık sağlamaktadır (Bestetti ve Saccani, 2014, s. 36).

Kil toprak pigmentleri genellikle doğal olarak oluşan metal oksit veya kil bazında küçük miktarlarda dağılmış hidroksit renklendiricilerden oluşur. Kolayca ve bol miktarda temin edilen bu pigmentler Paleolitik zamanlardan beri (15.000 yıl önce) sanatta kullanılmışlardır (Eastaugh ve diğerleri, 2004, s. 146), Altamira (İspanya) ve Lescaux'un (Fransa) mağara resimlerinde rastlanmıştır. Pigment üretmek için kullanılan teknolojik süreçler yüzyıllar boyunca birçok yazar tarafından belgelenmiştir (Manasse ve Mellini, 2006, s. 845). Günümüzde sanatçılar, yüksek kalıcılığa ve yoğunluğa sahip modern sentetik organik pigmentler ile zaman testini yapan doğal organik pigmentler ve inorganik pigmentlerin bir karışımını kullanmaktadır (Barnett ve diğerleri, 2006, s. 453).

İtalya'nın Toskana bölgesinde Floransa'nın güneyinde yer alan Siena şehri (Amiata Dağı'nın batı yamaçlarında bulunan toprak boya tortuları) önemli bir toprak renginin kaynağıdır. Bu, sarı-kahverengi bir renk olan Ham sienna'nın "Terra di Siena Naturale" rengidir (Crabtree ve Beudert, 2012, s. 176; Eastaugh ve diğerleri, 2004 , s. 339; Manasse and Mellini, 2006, s. 845; Panda, 2016, s. 51). Sienna yatakları ayrıca Amerika'da Lehigh Gap Pennsylvania'da ve Almanya'nın Harz Dağları'nda bulunmaktadır. Küçük miktarlarda Sicilya'da da üretilmektedir (Eastaugh ve diğerleri, 2004, s. 339; Santmyers, 1931, s. 15).

Ham Sienna $\left(\mathrm{FeO}(\mathrm{OH})+\mathrm{MnO}_{2}+\mathrm{Al}_{2} \mathrm{O}_{3} \cdot \mathrm{SiO}_{2} \cdot \mathrm{nH}_{2} \mathrm{O}\right)$

Yanmış Sienna $\left(\mathrm{Fe}_{2} \mathrm{O}_{3}+\mathrm{MnO}_{2}+\mathrm{Al}_{2} \mathrm{O}_{3} \cdot \mathrm{SiO}_{2} \cdot \mathrm{nH}_{2} \mathrm{O}\right)$

Ham sienna, demir oksit ve silikanın karışımından oluşan doğal toprak pigmentidir. Yaygın olarak geotit, oldukça yüksek oranda demir oksit (genellikle \%60 ila \%80) içerir. Antik çağlardan beri kullanılmaktadır. Renklendirme gücü iyi olan şeffaf bir pigmenttir. Renk tonu sıcak, koyu altın sarısı tonunda kahverengidir. Kalıcı bir pigmenttir, ancak saydamlığı ve keten tohumu yağının kırılma endeksindeki artış sebebiyle zaman içinde renk tonları derinleşir. Ham sienna okra ile yakın ilişkilidir. Her ikisi de limonit tipi cevherlerden elde edilir, ancak sienna genellikle daha yüksek demir içeriğine sahiptir ve rengi daha koyudur. Ayrıca az miktarda $(<\% 5)$ manganez oksit içerdiği için okralardan ayrılır (Eastaugh ve diğerleri, 2004, s. 146). Siennalar, yağ içinde dağıldıklarında bir miktar yarı saydamdır. Bu yarı saydamlığın demirin bir kısmı hidratlanmış demir oksit yerine demir silikat ve alüminatlar biçiminde olmasından kaynaklandığına inanılmaktadır (Laurie, 1967, s. 86; Manasse ve Mellini, 2006, s. 845; Panda, 2016, s. 51; Pascual ve Patino, 2003, s. 49; Santmyers, 1931, s. 2; Seymour, 2003, s. 109).

Ham siennanın kalsinasyonu sonucu (Barnett ve diğerleri, 2006, s. 448) demir hidroksitin demir oksite dönüşmesi sonucu, yaklaşık $270^{\circ} \mathrm{C}^{\prime}$ de goetitin dehidrasyonu ile elde edilen hematitten (Manasse ve Mellini, 2006, s. 845) Yanmış Sienna "Terra di Siena Bruciata" oluşur. Renk tonu sıcak, kızılımsı kahverengindedir. Zamanla kararma eğilimindedir (Vahur, 2010, s. 26). Pas gibi görünen demir oksit, zengin bir kırmızı-kahverengi rengin başka bir 
kaynağıdır, ancak karıştırıldığında diğer renkleri boğma eğilimindedir. Bu yüzden çoğu sanatçı yanmış sienna'yı demir okside tercih etmektedir (Crabtree ve Beudert, 2012, s. 176).

En erken örneklerine Altamira mağarasındaki kaya resimlerinde, MÖ 200-MS 600 MS Hindistan'daki Ajanta freskleri, Kıpti tuval resimleri, duvar resimleri ve ahşap oymacılığı ve İrlanda Orta çağ duvar resimlerinde, Akabe Camii, Kudüs'teki duvar resimlerinin orijinal ve restorasyon çalışmalarında, ayrıca çeşitli panel resimlerinde ve Çin tekstillerinde kullanılmıştır (Eastaugh ve diğerleri, 2004, s. 339-340). Michelangelo'nun Sistine Şapeli'ni boyadığı renk paletinde de kahverengi renkler için Yanmış Sienna kullandığı bilinmektedir (Mancinelli, 1991 , s. 59). Doğal toprak boyaları (okra-sienna-umber), ressamlara sarıdan kahverengiye, turuncudan kırmızıya, koyu kahverengiye ve neredeyse siyaha kadar yarı saydamlık derecesinde daha yumuşatılmış renk tonları sunmaktadır. Örneğin Rembrandt resimlerinin çoğunda bu doğal toprak pigmentleri, özellikle beyaz ve siyah ile diğer pigmentlerle birlikte önemli ölçüde kullanmıştır. On sekizinci yüzyılın sonuna doğru, bu toprak renklerinin bazılarının sentetik versiyonları geliştirilmiştir (Bomford ve Roy, 2009, s. 48).

Sienna pigmentinin İngilizleştirilmiş versiyonlarının ortaya çıktığı, ham ve sienna pigmentlerinin rutin kullanıma girdiği 19. yüzyıla kadar yanmış veya yanmamış olsun "Terra di Siena" Ham Sienna olarak adlandırıldığı söylenmektedir. Bazı kaynaklarda yanmış sienna "Amerikan” ve "İtalyan” olarak iki farklı versiyon olarak geçtiği görülmüştür. Her ikisi de ilgili ülkelerden elde edilen kalsine ham siennalar olsa da temel farkın rengin ince bir varyasyonunda olduğu ortaya çıkmıştır. Beyazla karıştırıldığında İtalyan mavimsi bir gölge verirken, Amerikan kahverengimsi/sarımsı bir renk tonu vermektedir (Eastaugh ve diğerleri, 2004, s. 66). Amerikan yanmış sienna \%25 ila 60 oranında demir oksit içermektedir. İtalyan yanmış sienna, ortalama \%60 ila 75 oranı ile Amerikan ürününden daha fazla demir içeren bir pigmenttir (Santmyers, 1931, s. 2).

19. yüzyılda endüstriyel ticaret için yaygın olarak kullanılan sienna pigmentleri, Orta Çağ ve Rönesans'in en önemli Toskana sanatçıları (ör. Duccio di Buoninsegna ve Ambrogio Lorenzetti) tarafından büyük ölçüde kullanılmıştır. Diğer kil toprak pigmentlerinin aksine, ham ve yanmış sienna, yüksek kaplama verimliliğine sahip parlak renklerdir (Manasse ve Mellini, 2006, s. 845). Ham ve yanmış sienna renkleri 1şığa karş1 oldukça dayanıklıdır, ancak Ham sienna yaklaşık $176{ }^{\circ} \mathrm{C}$ 'nin $\left(350{ }^{\circ} \mathrm{F}\right)$ üzerindeki sıcaklıklarda daha kırmızı bir tona dönüşmektedir. Siennalar ahşap dolgu ve renklendiricilerde kullanılmasının yanı sıra mimari boyalarda da kullanılmaktadır. Bununla birlikte, bu pigmentlerin daha güçlü ve temiz renge sahip olması nedeniyle, sentetik kırmızı ve sarı oksitler tarafından renk tonları değiştirilmektedir (Panda, 2016, s. 52).

Mora ve diğerleri’nin (1984, s. 305-306) kitabında, herhangi bir rötuş tekniği için kullanılacak pigmentin seçiminde kimyasal bileşimlerinin yaşlanma ve ışık dahil tüm atmosferik koşullara karşı dirençli olan pigmentlerin seçilmesi gerektiği vurgulanır. Bu pigmentler arasında Ham ve Yanmış Sienna pigmentleri bulunmaktadır. Boya pigmentleri olarak, çok kalıcıdırlar, iyi kaplama gücüne sahiptirler, değişiklik yapmadan diğer tüm dayanıklı pigmentlerle iyi karışırlar, asitlerden veya alkalilerden etkilenmezler (Santmyers, 1931, s. 4).

\section{Sonuç ve Tartışma}

Rötuşun sınırlarını belirlemek her zaman mümkün değildir; çoğu zaman konservatörün sübjektif bakış açısıyla değerlendirilerek uygulanmaktadır. Her eser kendi içinde değerlendirilmeli, onun için "uygun" olanın başka bir eser için uygun olamayabileceği unutulmamalıdır. Her zaman daha iyi bir ton, renk ve parlaklık bulunmaktadır. Farklı markaların bile aynı renklerinde farklı renk tonları ile karşılaşıldığı düşünüldüğünde çok geniş bir renk çeşitliliğiyle karşı karşıya olduğumuz bilinmelidir. Burada dikkat edilmesi gereken, orijinal boya tabakasının parlaklık, saydamlık ve dokusuna uygun olanın seçimine karar verilmesidir. Bu aşamada bağlayıcının özellikleri, çalışma ve uygulama kolaylığı, ıslanma ve yaşlanma (sararma) özelliği, stabilitesi ve geri dönüşlüğü oldukça önemlidir.

Özellikle yurtdışında konuyla ilgili yayınlar sıkça yayımlanmakta ve deneysel çalışmalarla desteklenmektedir. Bailao ve Cardeira'nın (2017, s. 248-255) yayınladıkları çalışmada bu araştırmaya konu olan boya ve bağlayıcılardan bahsedilmiş fakat uygulama yapılarak değerlendirilmemiştir. Bestetti ve Saccani (2014, s. 26-38) tarafından hazırlanan yayın Laropal A81 ve Paraloid B72'nin; Lowry (2010, s. 87-91) ise sadece Paraloid B72'nin rötuş boyası olarak hazırlanması ve uygulanması üzerine yapılan çalışmaları ele almıştır. Cardeira ve diğerleri'nin (2017, s. 88-96) çalışması suluboya markörlerinin belli bir renksel tamamlama tekniğinde değerlendirilmesi üzerinedir. Bahsi geçen yayınlar çalışma kapsamında yararlanılan ve referans olarak alınan kaynaklardır. Rötuş malzemelerine yönelik benzer çalışmalar üretilmekle birlikte, yapılan bu çalışma kapsamında geçmişte ve günümüzde kullanılan rötuş boyaları açıklanmış, bir pigment türü üzerinden deneysel uygulama yapılarak rötuş boyaları karşılaştırılmıştır.

Çalışma kapsamında, Winsor\&Newton, Schminke ve Lucas gibi markaların tüp suluboyaları kullanılmıştır. Şüphesiz bu çeşitlilik çoğaltılabilir, renk tonları üzerinde tartışılabilir. Çalışmanın amacı mümkün olduğunca farklı boya türlerinin karşılaştırılması olduğu için tüp suluboyalar üç farklı marka ile sınırlandırılmıştır. Lucas marka sulu boyalar Winsor\&Newton ve Schminke'ye göre daha koyu tonlarda renk vermektedir. Winsor\&Newton guaj 
boyanın örtücülüğü suluboyalara göre daha iyidir. Suluboya markörlerinin kullanımı rahattır. Fakat renk çeşitliliğinin azlığı ve renklerin karışımına uygun olmadığı için her zaman tercih edilmesi mümkün değildir. Maimeri Restauro hazır ve vernikli bir boya olması sebebiyle parlaklığı ile diğer boyalara kıyasla rötuş için daha uygundur. Fakat kullanımı sırasında çözücüyle sık s1k 1slatılması gerekmektedir. Konservatörler tarafından Laropal A81 ve Paraloid B72 ile hazırlanan rötuş boyalarının yapım süreci zahmetli olsa da uygun pigment ve bağlayıcı oranı sağlandıktan sonra kullanışlı boyalar elde edilmektedir. Bu boyalar bağlayıcı sebebiyle her iki dolgu malzemesinde de oldukça parlak bir görüntü vermektedir. Diğer vernikli boyada olduğu gibi rötuş sırasında bağlayıcının çözücüsüyle sıkça islatılmalıdır.

Dolgu malzemesi olarak kullanılan Modostuc'un suda çözünen yapısı nedeniyle sulu boyaların uygulanması esnasında çözünmeye başlayarak boya ile birleştiği gözlenmiştir. Bu da yüzeyde oldukça opak-puslu bir görünüme sebep olmaktadır (Bknz. Görsel 6). Stik suluboyaların uygulanışı sulu kalemlerle yüzeye dağıtılabilir. Fakat Modostuc üzerine uygulanması suda çözünmeye elverişli olması sebebiyle için çok uygun görünmemektedir. Su ve pigment bağlayıcılarının çözücülerinden hızlı bir şekilde etkilenen dolgu malzemesi yüzey üzerinde boya ile detaylı çalışılmasına çok fazla izin vermemektedir. Küçük çatlak ve deliklerin dolgularında kullanılması daha uygun görünmektedir. Eserin bu malzeme ile dolgulanıp verniklendikten sonra rötuşlanması halinde de kullanımı uygun hale gelebilmektedir.

Suluboyaların tavşan tutkalı ve Bologna alçısıyla hazırlanan dolgu üzerinde dağılımı ve uygulanışı rahattır. Modostuc içerikli dolguya göre suya karşı direnci daha kuvvetlidir. Bu özellik rötuş uygulamalarında dolgu malzemesi olarak tercih edilmesinin güçlü bir nedenidir. Dezavantajı ise hayvansal tutkal ile karıştırılan alçının zaman içinde sararma ve mikroorganizmalara açık hale gelebilmesidir. Bunun için tutkala mantar önleyici benzeri malzemelerin eklenmesi gerekmektedir.

Tüm değerlendirmeler 1şı̆̆ında, Modostuc'un nem çekme ve suda çözünme özelliği sebebiyle küçük alanlar için uygulanabilir fakat büyük dolgu alanları için dolgu üzerine vernikleme yapıldıktan sonra rötuş yapılmasıyla ideal dolgu malzemesi olduğu söylenebilir. Rötuş boyalarının maliyetli olması ve zor bulunması sebebiyle suluboya ve türevleri kullanılsa da piyasada bulunan malzemeleri uyarlamak yerine Dunkerton'un da (2010, s. 100) dediği gibi "rötuş için tasarlanmış boyaları kullanmak idealdir." Her geçen gün rötuş malzemeleri ile ilgili yeni malzemeler ve gelişmeleri takip etmek mümkündür. Fakat gelişim, malzemelerin pratikte kullanımı, uygulanması ve sonuçlarının karşılaştırılmasıyla devam edecektir. Ruhemann'ın (1968, s. 243) bugün ve gelecekte geçerli olan bir sözü şöyledir: "Henüz hiçbir ideal rötuş bağlayıcısı bilinmemektedir". 


\section{Kaynakça}

Ackroyd, P. (2010). Retouching media used at the National Gallery, London, since nineteenth century. R. Ellison, P. Smithen \& R. Turnbull (Eds.), Mixing and matching, approaches to retouching materials (s. 51-60) içinde. Archetype Publications.

Bailao, A. \& Cardeira, L. (2017, October). Mixing and matching: A survey of retouching materials. 4th International Meeting on Retouching of Cultural Heritage, RECH4 (s. 248-255) içinde. https://www. academia.edu/37522202/MIXING AND MATCHING A SURVEY OF RETOUCHING MATERIALS

Barnett, J. R., Miller S., \& Pearce, E. (2006). Colour and art: A brief history of pigments. Optics\&Laser Technology, 38, 445-453. https://doi.org/10.1016/j.optlastec.2005.06.005

Bestetti, R., \& Saccani, I. (2014, October). Materials and methods for the self-production of retouching colours, Laropal A81, Paraloid B72, Gum Arabic and Aquazol based colours. 2nd International Meeting on Retouching of Culture Heritage, RECH2 (s. 26-38) içinde. https://www.academia.edu/20442261/Materials_and_methods for the self_production_of_retouching_colors_Laropal_A81_Paraloid_B72_Gum_Arabic_and_Aquazol_ba sed colors

Bomford, D., \& Roy, A. (2009). A closer look, colour. National Gallery Company Limited.

Bucklow, S. (2010). The state of research into retouching resins. R. Ellison, P. Smithen \& R. Turnbull (Eds.), Mixing and matching, Approaches to retouching materials (s. 61-65) içinde. Archetype Publications.

Cardeira, L., Bailao, A., Linhares, J., \& Nascimento, S. (2017, October). Using watercolour markers in chromatic reintegration. 4th International Meeting on Retouching of Cultural Heritage, RECH4 (s. 88-96) içinde. https://www.academia.edu/37522184/USING WATERCOLOUR MARKERS IN CHROMATIC REINTE GRATION

Crabtree, S., \& Beudert, P. (2012). Scenic art for the theatre, history, tools and techniques (3rd Edition). Routledge.

Çağlar Eryurt, B. (2020). Modostuc, bologna alçısı, boya, pigment ve bă̆layıcılar [Fotoğraf]. Berna Çağlar Eryurt kişisel arşivi.

Digney Peer, S., Thomas, K., Perry, R., Townsend, J., \& Gritt, S. (2013). The imitative retouching of easel paintings. J. Hill Stoner ve R. Rushfield (Eds.), Conservation of easel paintings (s. 607-634) içinde. Routledge.

Dunkerton, J. (2010). Retouching with Gamblin conservation colors. R. Ellison, P. Smithen ve R. Turnbull (Eds.), Mixing and matching, approaches to retouching materials (s. 92-100) içinde. Archetype Publications.

Eastaugh, N., Walsh, V., Chaplin, T., \& Siddall, R. (2004). The pigment compendium: A dictionary and optical microscopy of historical pigments. Elsevier-Butterworth Heinemen.

Fernandez Villa, S. G. (2015, October). Filling as retouching: The use of coloured fillers in the retouching of contemporary matte paintings. 3rd International Meeting on Retouching of Cultural Heritage, RECH3 (s. 199207) içinde. https://eprints.ucm.es/id/eprint/42499/1/Pa\%CC\%81ginas\%20desdeRech3PublicacDef.pdf

Fuster Lopez, L., Mecklenburg, M. F., Castell Agusti, M., \& Guerola Blay, V. (2008). Filling materials for easel paintings: when the ground reintegration becomes a structural concern. J.H. Townsend, T. Doherty, G. Heydenreich ve J. Ridge (Eds.), Preparation for painting: The artist's choice and its consequences (s. 180186) içinde. Archetype Books.

Gamblin. (t.y.). Pigmented wax/resin for the conservation of paintings. https://gamblincolors.com/conservationcolors/pigmented-wax-resin/

Goldenpaints. (t.y.). High load acrylic colors. https:/www.goldenpaints.com/products/custom-products/highload-acrylic-colors

Hirci, G. B., \& Ramovs, L. M. (2015, October). Use of retouching colours based on resin binders- from theory into practice. A. Bailão, F. Henriques \& A. Bidarra (Eds.), 3rd International Meeting on Retouching of Cultural Heritage, RECH3 (s. 45-52) içinde. Escola Artística e Profissional Árvore. https://www.academia.edu/29462514/USE_OF_RETOUCHING_COLOURS_BASED_ON_RESIN_BINDE RS_FROM THEORY_INTO_PRACTICE

Kempski, M. (2010). The art of tempera retouching. R. Ellison, P. Smithen ve R. Turnbull (Eds.), Mixing and matching, approaches to retouching materials (s. 36-46) içinde. Archetype Publications. 
Koneczny, P. (2010a). Properties of pigments and retouching media and their use. R. Ellison, P. Smithen ve R. Turnbull (Eds.), Mixing and matching, approaches to retouching materials (s. 66-73) içinde. Archetype Publications.

Koneczny, P. (2010b). An introduction to B72 retouching gel. R. Ellison, P. Smithen ve R. Turnbull (Eds.), Mixing and matching, approaches to retouching materials (s. 142-147) içinde. Archetype Publications.

Laurie, A. P. (1967). The painter's methods and materials. Dover Publications.

Lowry, K. (2010). Retouching with Paraloid B-72. R. Ellison, P. Smithen ve R. Turnbull (Eds.), Mixing and matching, approaches to retouching materials (s. 87-91) içinde. Archetype Publications.

Manasse A., \& Mellini, M. (2006). Iron (hydr)oxide nanocrystals in raw and burnt sienna pigments. European Journal of Mineralogy, 18(6), 845-853. https://doi.org/10.1127/0935-1221/2006/0018-0845

Mancinelli, F. (1991). The frescoes of Michelangelo on the vault of the Sistine Chapel: Conservation methodology, problems, and result. S. Cather (Eds.), The conservation of wall paintings (s. 57-66) içinde. The Getty Conservation Institute. https://hosting.iar.unicamp.br/lab/luz/ld/Arquitetural/Museus/Conserva\%e $7 \% \mathrm{e} 3 \mathrm{o} /$ wall_paintings.pdf

Massing, A. (2010). The history of egg tempera as a retouching medium. R. Ellison, P. Smithen ve R. Turnbull (Eds.), Mixing and matching, approaches to retouching materials (s. 5-17) içinde. Archetype Publications.

McIntyre, C. (2011). Development of a pigmented wax/resin fill formulation for the conservation of paintings. Art Conservation Department. https://gamblincolors.com/wp-content/uploads/2016/01/McIntyre_695_To_ Gamblin_2014.pdf

Mora, P., Mora L., \& Philippot, P. (1984). Conservation of wall paintings. Butterworths.

Nicolaus, K. (1999). Restoration of paintings. Könemann.

Panda, H. (2016). Modern technology of textile dyes\&pigments. NIIR Project Consultancy Services.

Pascual, E., \& Patino, M. (2003). O restauro de pintura. Editorial Estampa.

Pentier, G. (2015). Structuring at the retouching step. 2nd International Meeting on Retouching of Culture Heritage, RECH2 (s. 191-208) içinde. http://e-conservation.org/downloads/finish/2-issues/3-issue2/0

Ramovs, L. M., \& Hirci, B. G. (2008). Retouching: How and with what? International workshop on retouching oil paintings and wooden polychrome sculpture. Varstvo spomenikov, 44, 222-227. http://www.eheritage.si/vs/ VSC 044C 018 HADVRSRHIGDMMQPDHIPJIFVEPIWFLM.pdf

Ruhemann, H. (1968). The cleaning of paintings: Problems and potentialities. Faber\&Faber Limited.

Santmyers, R. M. (1931). Umber, sienna, and other brown earth pigments. Department of Commerce, United States Bureau of Mines.

Seymour, P. (2003). The artist's handbook: A complete professional guide to materials and techniques. Arcturus Publishing Ltd.

Soltan, M. A. A. (2015). An Investigation into the History of the Airbrush and the Impact of the Conservation Treatment of Airbrushed Canvas Paintings (Yayin No. 27304) [Doktora Tezi, Northumbria University]. http:/nrl.northumbria.ac.uk/id/eprint/27304/1/soltan.mohamed_phd.pdf

Szmit Naud, E. (2003). Research on Materials for Easel Painting Retouches Part 1. The Picture Restorer, 23, 5 10. https://www.academia.edu/33117470/Research on Materials for Easel Painting Retouches Part 1 The Picture Restorer_n_23 Spring_2003_pp 5 _ 10

Vahur, S. (2010). Expanding the possibilities of ATR-FT-IR spectroscopy in determination of inorganic pigments, institute of chemistry, faculty of science and technology (Yayın No. 1406-0299) [Doktora Tezi, Tartu University]. http://dspace.ut.ee/bitstream/handle/10062/14740/vahur signe.pdf?isAllowed=y\&sequence=1 